Asian-Australasian Journal of

Food Safety and Security

ISSN 2523-1073 (Print) 2523-2983(Online)

https://www.ebupress.com/journal/aajfss/

\title{
Article \\ A potential endemic cyprinid for aquaculture and food security: The embryonic development of the Bornean spotted barb Puntius sealei (Herre, 1933)
}

\author{
Lirong Yu Abit, Edmond Felix Unggang, Abdulla-Al-Asif and Kamil Latif*
}

Department of Animal Science and Fisheries, Faculty of Agricultural Science and Forestry, Universiti Putra Malaysia Bintulu Sarawak Campus, Jalan Nyabau 97008, Bintulu, Sarawak, Malaysia

*Corresponding author: Kamil Latif, Department of Animal Science and Fisheries, Faculty of Agricultural Science and Forestry, Universiti Putra Malaysia Bintulu Sarawak Campus, Jalan Nyabau 97008, Bintulu, Sarawak, Malaysia. E-mail: kamill@upm.edu.my

Received: 25 August 2021/Accepted: 23 November 2021/ Published: 30 November 2021

Copyright ( 92021 Lirong Yu Abit et al. This is an open access article distributed under the Creative Commons Attribution 4.0 International License (https://creativecommons.org/licenses/by/4.0/), which permits unrestricted use, distribution, and reproduction in any medium, provided the original work is properly cited.

\begin{abstract}
The Bornean Spotted Barb is endemic fish species and widely distributed throughout Borneo in various freshwater bodies and can be considered as a potential aquaculture candidate for food security and the ornamental trade. However there has yet to be scientific studies on the early life history and developmental stages of this species. Thus the present study reveals the embryonic development of Puntius sealei embryo, from fertilization to post-hatching using the induced breeding method. The induced spawning on $P$. sealei using Ovaprim hormone at a dose of $0.5 \mathrm{ml} / \mathrm{kg}$ for females and $0.25 \mathrm{ml} / \mathrm{kg}$ for males respectively was successfully conducted and the embryonic development of the fertilized eggs were observed. The zygote, cleavage, blastula, gastrula, segmentation, and larval phases were the six major stages of embryogenesis that investigated in this experiment. This study contributed major knowledge to the early developmental biology of this particular species. The information will be useful for accessing the potentiality of this species for aquaculture as well as the management, and production of the species.
\end{abstract}

Keywords: ornamental fish; induced breeding; embryogenesis; zygote; segmentation

\section{Introduction}

Puntius sealei (Herre, 1933), or commonly known as the Bornean Spotted Barb, is a cyprinid fish endemic to the Island of Borneo, especially in Malaysian provinces of Sarawak and Sabah (Chong et al., 2010; Doi et al., 2001; Froese and Pauly, 2021; Grinang, 2013; Hui and Ng, 2005; Kottelat, 2012; Pethiyagoda et al., 2012; Sadi and Biun, 2012; Wilkinson and Hui, 2018). This species was also reported from, freshwater ecosystems of Brunei Darussalam, and Kalimantan of Indonesia, which are also known as Borneo (Hui and Husana, 2021; $\mathrm{Ng}$ and Tan, 2021; Sulaiman et al., 2018; Sule et al., 2016). Puntius sealei is a hardy freshwater benthopelagic fish that has a cosmopolitan distribution throughout freshwater streams in Borneo (Jimmy et al., 2010). Throughout its range, Puntius sealei has been found to be common and plentiful in many locations (Martin-Smith, 1996; Rachmatika et al., 2005). The presence and abundance of fish species inhabiting a water body is a good indicator of condition of the habitat where they can be found as well as the robustness of the species, with Puntius sealei found in almost all lotic and lentic habitats throughout Borneo is a clear indication of the ability of this species to cope under diverse conditions (Rachmatika et al., 2005; Yu Abit et al., 2012). Puntius sealei can be distinguished from other congeners by the four circular or oval black spots on the middle side of their body in addition to another small dark spot also on the anterior base of the dorsal and sometimes on the anal fins (Kottelat et al., 1993). This fish species is of moderate economic significance as a food fish throughout their 
distribution range being sold either fresh or prepared as a fermented fish ("Kasam ikan"in the local Malay language). Puntius sealei is a medium sized fish which can reach a maximum total length of $13.7 \mathrm{~cm}$ (Kottelat $e t$ al., 1993). Currently Puntius sealei has been evaluated on the International Union for Conservation of Nature and Natural Resources (IUCN) Redlist of Least Concern (LC) (Rodolfo, 2021). In recent times there has been interest in other native cyprinids of Southeast Asia such as Tor tambroides for both food and ornamental purposes (Ismail et al., 2019, 2020). There are potential to develop the aquaculture of Puntius sealei for food security or as a native ornamental fish alternative to non-native species which are currently being cultured. Breeding biology, broodstock management and induced breeding of some Cyprinidae fishes were previously studied hugely by certain groups of scientists, while the Puntius sealei found mostly poorly studied fish among the family (Hossain et al., 2016; Islam et al., 2016; Islam et al., 2017; Mondal et al., 2020; Rahman et al., 2017; Rahman et al., 2016; Yeasmin et al., 2016, 2018). Currently there are lack of data regarding the basic biology of Puntius sealei including the method of induced breeding, embryonic development and larviculture of this species. Thus the current study attempts to be the first record of induced breeding, embryonic and larval development of Puntius sealei.

\section{Materials and Methods}

\subsection{Study location and periods}

Quantitative samples of fish were taken from 3 streams within the Universiti Putra Malaysia Bintulu Campus (UPMKB) area (Figure 1). All of the sampling sites were accessible by road or by foot (within $2 \mathrm{~km}$ radius of the main road). Streams were of approximate $<5 \mathrm{~m}$ maximum width and $200 \mathrm{~cm}$ maximum depth. Fish were collected using a variety of methods including scoop nets, baited traps and gill nets. Only Puntius Sealei were kept and all other fish species were returned to their original habitats. The sampled fishes were subsequently selected as the broodstock for induced breeding trials. A total of 6 adult males and 10 adult female P. sealei were captured. Sexually mature $P$. seale $i$ were identified and selected by applying slight pressure at the vent to inspect for any oozing of milt and reddish gonopores. The induced breeding trials were carried out from 9th May 2021 to 11th May 2021, at the Aquatic Biotech Laboratory and Wet Laboratory, Academic Centre Complex, Department of Animal Science and Fisheries, Faculty of Agricultural Science and Forestry, Universiti Putra Malaysia Bintulu, Sarawak Campus.

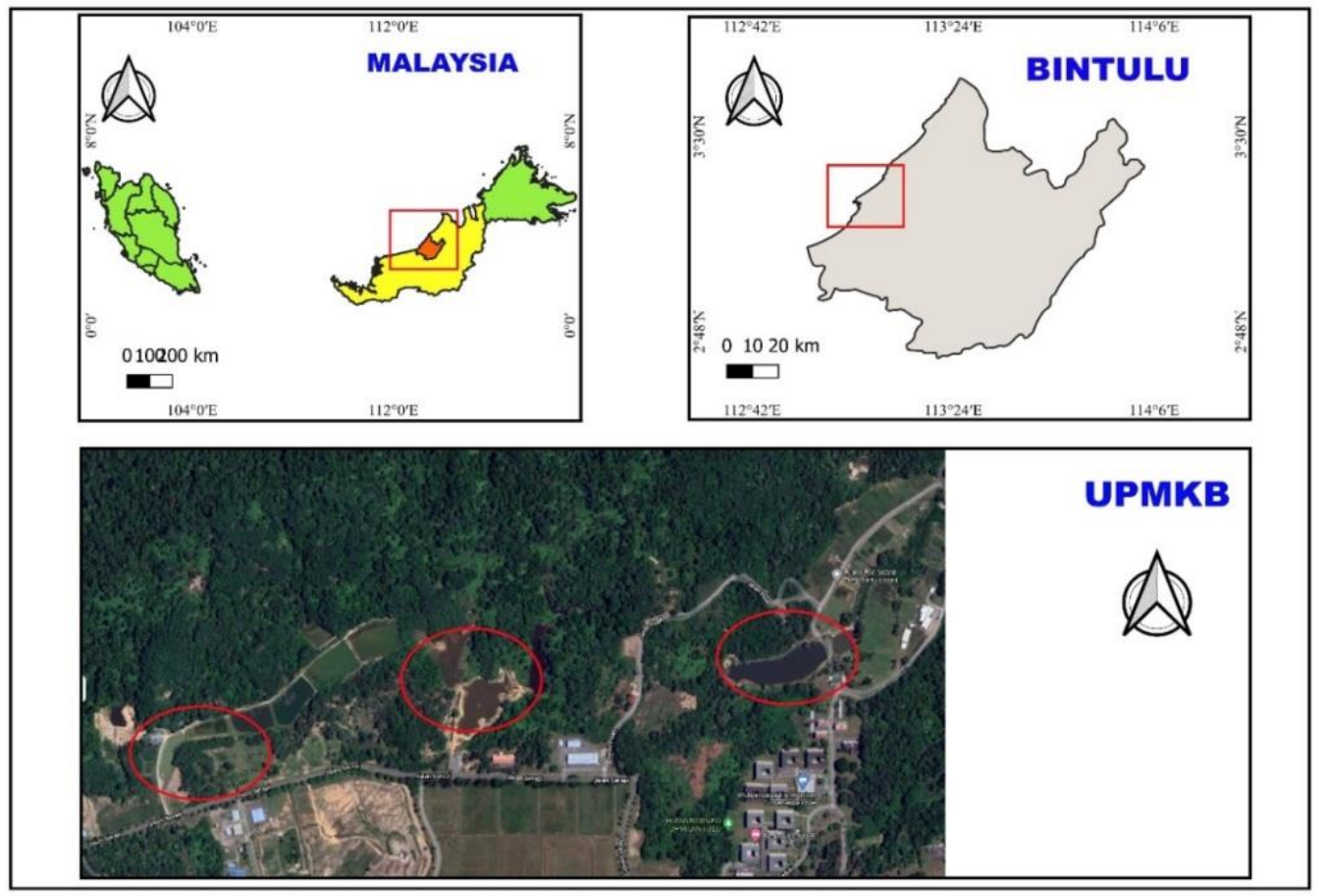

Figure 1. Map of streams in UPMKB where Puntius sealei were collected.

\subsection{Preparation of Brood and hatchery procedure}

Broodstock were sexed and males and females were kept separately in two aerated $450 \mathrm{~L}$ plastic fish tanks. The fish were fed twice a day till satiation with commercial floating starter pellets (Cargill). Fish were acclimatized 
for one week before the onset of the breeding trials. During the hypophysation, fish were anesthetized using Tricane Methane Sulphonate MS-222 at a $65 \mathrm{ppm}$ solution. Induced spawning for this was carried out using Ovaprim ®Syndel which is an analogue of Salmon GnRH [Ovaprim $1 \mathrm{~mL}$ contains $20 \mathrm{pg}$ of GnRH and $10 \mathrm{mg}$ domperidon]. Ovaprim has been shown to be effective in inducing spawning in Cyprinid fish (Epasinghe et al., 2016). Using an ultra- fine syringe $0.5 \mathrm{ml}, 29 \mathrm{~g}(0.33 \mathrm{~mm}) \times 12.7 \mathrm{~mm}$ was injected intramuscularly into the base of the dorsal fin at a dose of $0.5 \mathrm{ml} / \mathrm{kg}$ for female fish and $0.25 \mathrm{ml} / \mathrm{kg}$ for the male fish. After injection, the fish were returned to their holding tanks and were inspected at 6 hour intervals for any signs of spawning. After 12 hours fish were stripped of their eggs and milt into a plastic bowls and fertilization was carried out by mixing using a chicken feather. The fertilized eggs were poured in a single layer onto a hatching net and were incubated in a well aerated 25 liter aquaria containing 20 liters of treated freshwater.

\subsection{Embryonic and larval development analysis}

Embryonic and larval development was observed under a dissecting microscope and photographed. The eggs were photographed at every 1-hour interval up to hatching using a Leica Zoom 2000 (Model, Gxm L3200) and Leica CME microscopes inserting 40 to $100 \mathrm{X}$ magnifications. The diameters of the eggs were measured and recorded to calculate the average diameter.

\section{Results}

\subsection{The early embryonic development stages of Puntius Sealei}

The developmental stages were grouped into larger time blocks called Periods which consisted of the Zygote period, Cleavage period, Blastula period, Gastrula period and Segmentation period (Table 1).

\section{Table 1. Periods during the early embryonnic development of Puntius Sealei.}

\begin{tabular}{lll}
\hline Period & Period & Description \\
\hline $\begin{array}{l}\text { Zygote } \\
\text { Cleavage } \\
\text { Blastula }\end{array}$ & $\begin{array}{l}\text { 0 hours } \\
40 \text { minutes } \\
2 \text { hours }\end{array}$ & $\begin{array}{l}\text { Cytoplasm streams towards the animal pole to form the blasto-disc. } \\
\text { Blastomeres became arranged in more than one row. } \\
\text { Cell division transits from synchrony to asynchrony at mid-blastula transition; } \\
\text { yolk syncytial layer forms and epiboly begin. } \\
\text { Involution, convergence and extension occurred, forming the primary germ layers } \\
\text { and embryonic axis. }\end{array}$ \\
$\begin{array}{l}\text { Segmentation } \\
\text { Larvae/ Hatching }\end{array}$ & $\begin{array}{l}\text { Somites developed and organogenesis occurred, formation of tail. } \\
23 \text { hours }\end{array}$ & \begin{tabular}{l} 
Hatching occurred. \\
\hline
\end{tabular}
\end{tabular}

\subsubsection{Zygote period ( 0 - 40 minutes) of $P$. sealei}

The fertilized egg remains in the zygote stage until around 40 minutes after fertilization, when the first cleavage occurs. The completely expanded egg had a diameter of roughly $0.045 \mathrm{~mm}$. This expansion occurs between 7 to 10 minutes after fertilization. The cytoplasmic motions are activated during fertilization, resulting in the separation of the non-yolky cytoplasmic blastodisc from the clearer yolk granule-rich vegetal cytoplasm (Figure 2).

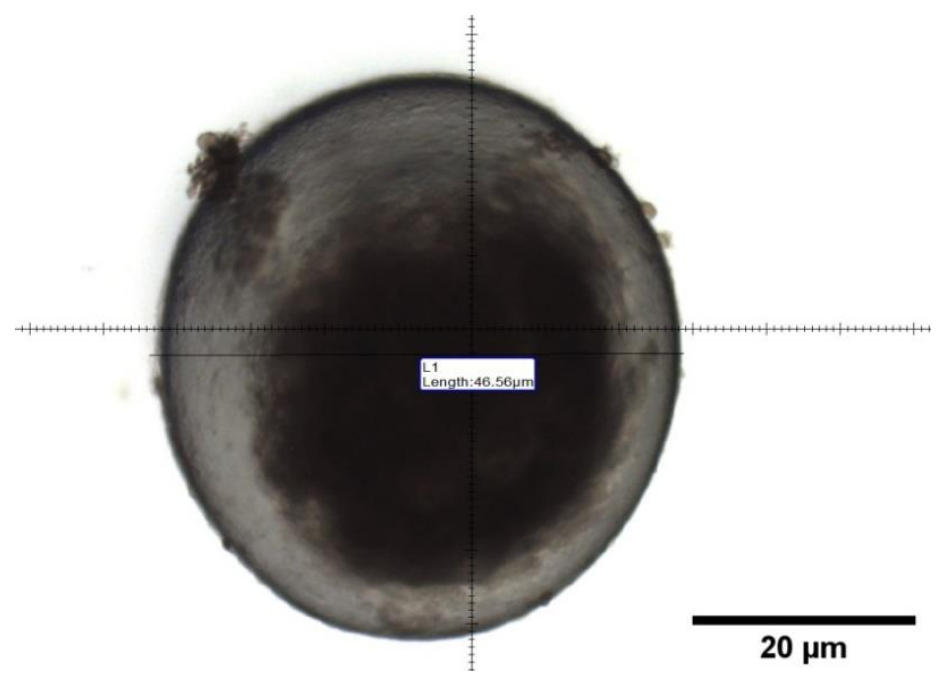

Figure 2. Zygote period of $P$. sealei. 


\subsubsection{Cleavage period ( 40 minutes -2 hours) of $P$. seale $i$}

The cells are seen to divide after the first cleavage until the early stages of the cleavage period. This causes the cells to become gradually smaller as the cleavage continues. The cells are divided into two distinct cells by vertical cleavage as it emerges at the vegetal pole and moves quickly toward the animal pole, passing through the blastodisc rather than the yolk. Continuously the cell in the egg multiplied into 2 cells, then 4 cells, 8 cells, 16 cells, 32 cell, and 64 cells respectively. The sixth cleavage, which also marks the first horizontal split, marks the conclusion of the cleavage period. It starts on one side of the blastodisc and works its way around to the other, producing two layers of 32 blastomeres, one lying on top of the other (Figure 3).

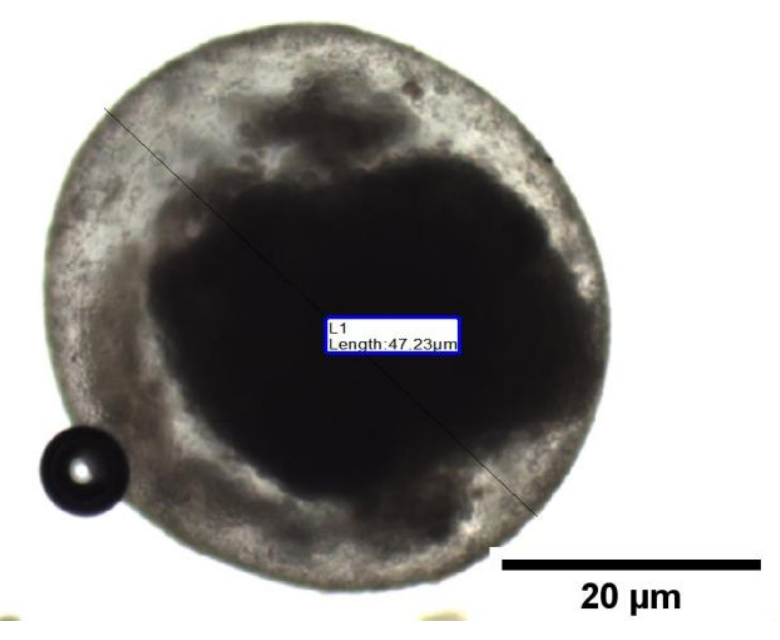

Figure 3. Cleavage period (40 minutes - 2 hours) of $P$. sealei.

\subsubsection{Blastula period ( 2 hours $-5 \frac{3}{4}$ hours) of $P$. sealei}

The period between when the blastodisc looks like a ball at the 128-cell stage and the beginning of gastrulation is known as the blastula. Cleavages in the early blastula stage continue in the same synchronized and rhythmic pattern as before. A single ring of numerous nuclei is frequently visible in the yolk syncytial layer at the mark of $1 \mathrm{k}$-cell stage or the ninth cleavage. Because of the continual shortening near the animal-vegetal axis, the last stage of blastula appears smooth and practically spherical in shape. For the following several hours, the overall spherical shape remains unaltered until gastrulation begins. From this stage until epiboly ends, the extent to which the blastoderm has extended across the yolk cell can be used as a marker (Figure 4).

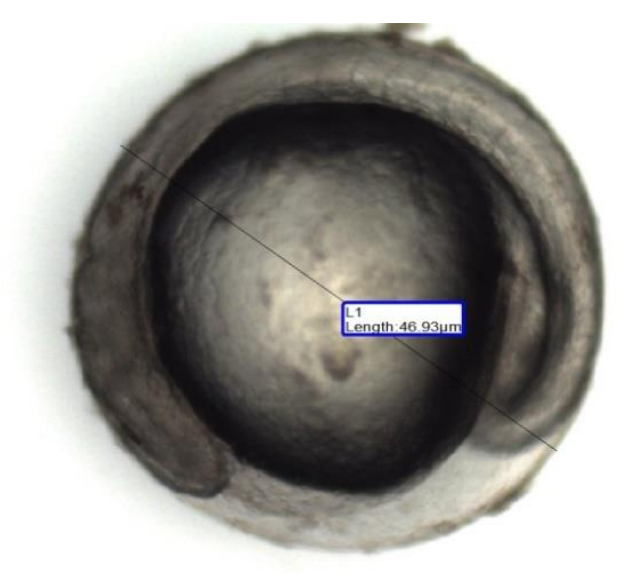

$20 \mu \mathrm{m}$

Figure 4. Blastula period ( 2 hours $-5 \frac{3 / 4}{4}$ hours) of $P$. sealei. 


\subsubsection{Gastrula period ( 5 3/4 hours - 8 hours) of $P$. sealei}

The beginning of gastrulation was defined by $50 \%$ epiboly after 4 hours and 25 minutes. The blastoderm margin covers the intervals between the animal and vegetable axes. The germ ring is formed by the expanded annulus at the blastoderm border. As the blastoderm almost completely covers the yolk plug, it can be seen protruding from the vegetal pole. When the blastoderm completely covers the yolk plug, epiboly is complete (Figure 5).

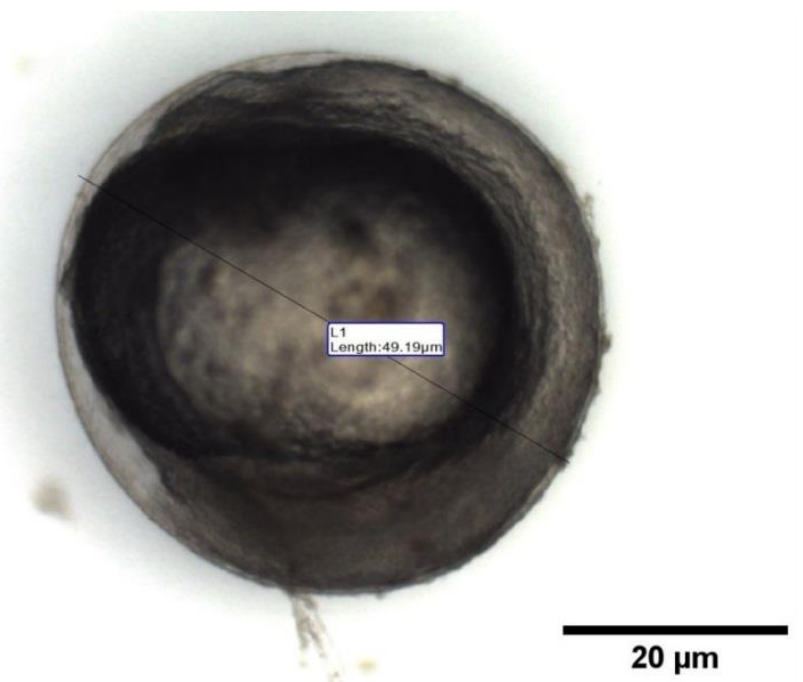

Figure 5. Gastrula period (5 3/4 hours - 8 hours) of $P$. sealei.

\subsubsection{Segmentation period ( 8 hours -23 hours) of $P$. seale $i$}

Segmentation and somite formation begin after epiboly, resulting in the 2-somites stage, 6- somites stage, 12 somites stage, 18-somites stage, 20-somites stage, and 30-somites stage, respectively. 12 hours after fertilization, the embryo turn into a transparent larva. During this time, the somites develop in an anterior-toposterior order, the basics of the principal organs appear, the tail bud becomes more apparent, and the embryos lengthen (Figure 6).

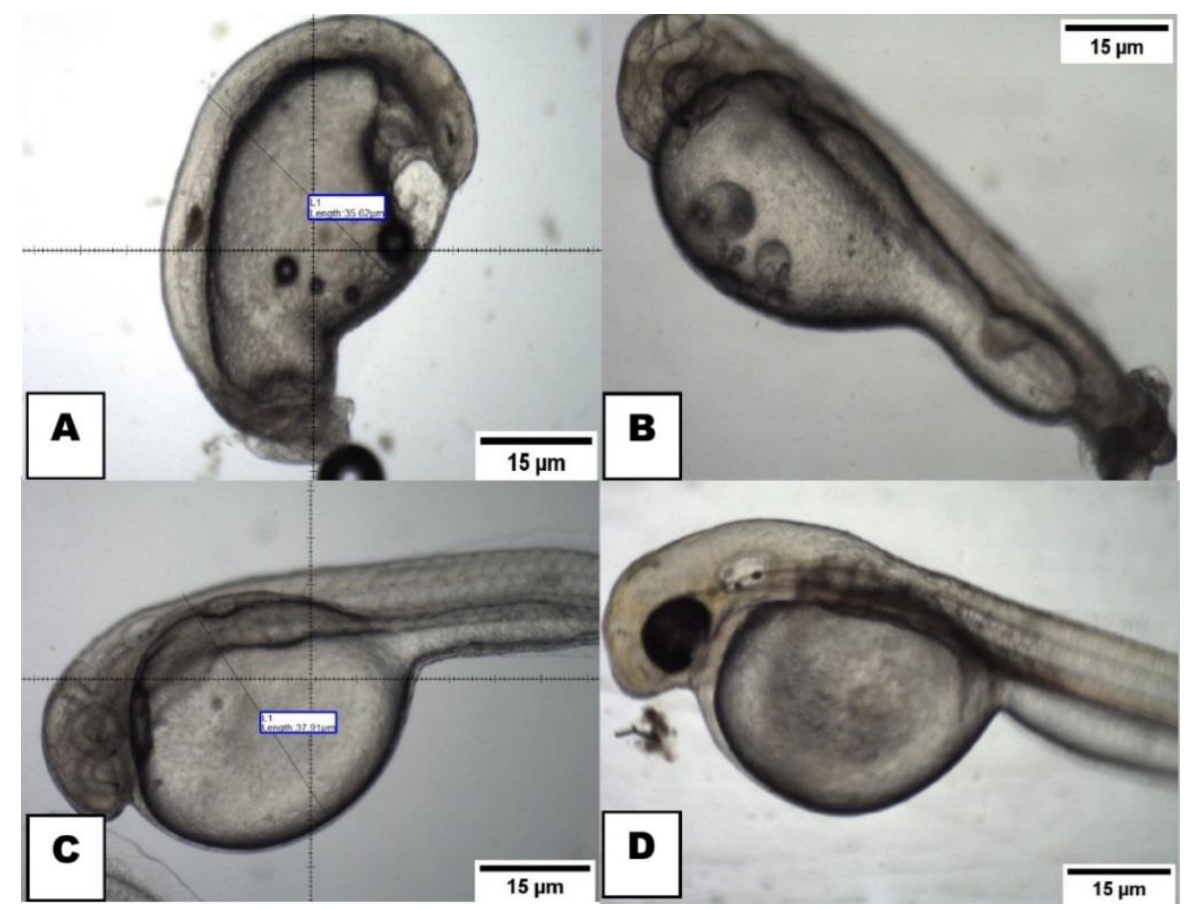

Figure 6. A, Segmentation period of the somite stage; B, development; C, Sac and tail appeared; D, eyes appeared. 
3.1.6. Larval period ( 23 hours - 48 hours) of $P$. sealei

Around 23 hours after fertilization, the first embryos hatched began to hatch from their eggs. The newly hatched larva is completely opaque due to the lack of pigmentation. About 2 to 3 hours after hatching, eye pigmentation begins to appear. The larva's pectoral fins are fully formed and functional, allowing them to swim freely. The size of the yolk ball shrinks as the larva grows. Pigmentation in the eyes and spots increases. The larva becomes less translucent and begins to move around more actively (Figure 7).

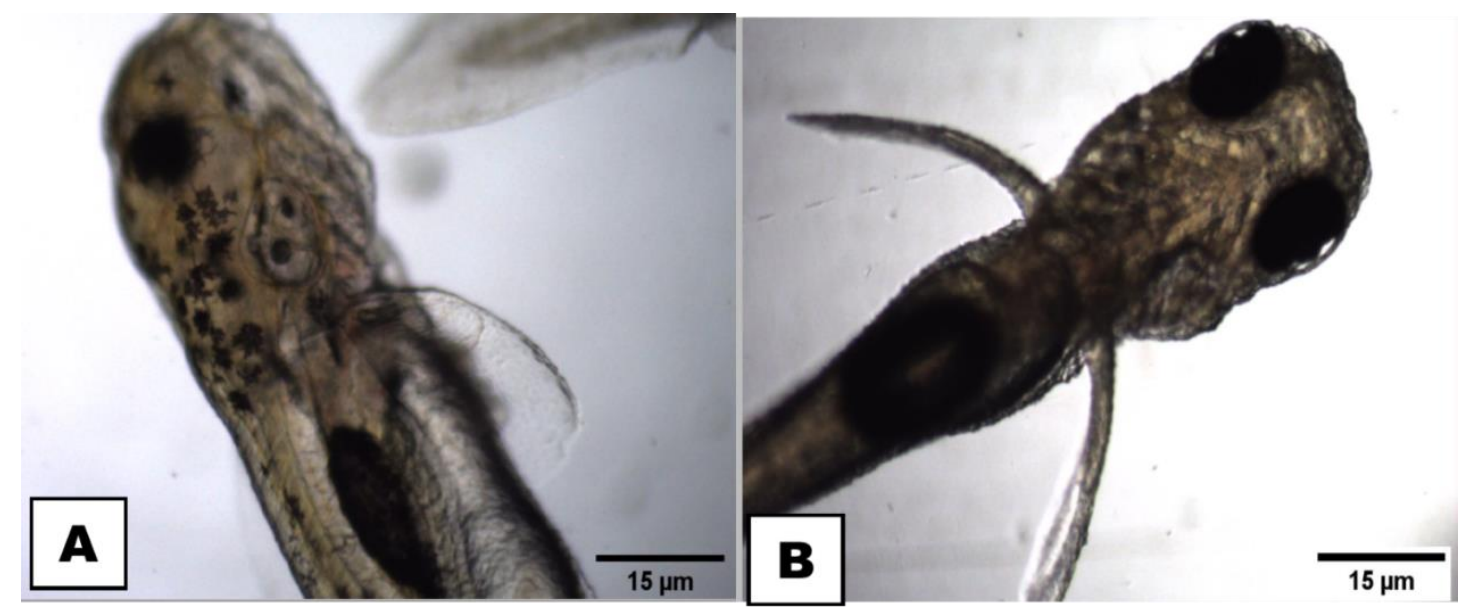

Figure 7. A, Melanophore visible on the larvae three days after hatching; B, Pigmentation visible on the dorsal area of the larvae three day after hatching.

\section{Discussion}

Puntius sealei is considered one of the important endemic barb species from the genus Puntius in Borneo Island (Wilkinson and Hui, 2018). Upon the declaration of this species in 1933, this fish still in the hand of taxonomists and conservationists, while they reported it as bio-indicator of alpha ecosystems (Rachmatika et al., 2005). Puntius sealei was not widely investigated previously due to lack of sufficient data, lack of interest amongst scientists, technical capabilities and expertise, while now as a potential candidate of aquaculture or ornamental fish species this species drawn more attention and new information about this species is going to be revealed. However this investigation revealed the induced breeding of Puntius sealei, while it required $0.5 \mathrm{ml} / \mathrm{kg}$ of Ovaprim induced hormone for female and $0.25 \mathrm{ml} / \mathrm{kg}$ for the male fishes. These findings are close to the study of Epasinghe et al. (2016) suggested $0.4-0.5 \mathrm{ml} / \mathrm{kg}$ of body weight Ovaprime for female, while they also suggested half dose for male fishes, but Puntius sealei could be induced with $0.25 \mathrm{ml} / \mathrm{kg}$ of male body weight. This study suggested the six embryonic development stages of experimental species namely, zygote, cleavage, blastula, gastrula, segmentation, and larvae/ hatching stage. The study of Bhattacharya et al. (2005) suggested six stages of embryonic development in rosy barb Puntius conchonius, but the study of Basak et al. (2014) suggested eight stages in Barbodes gonionotus in a pilot hatching setup within laboratory condition. Another study from Myanmar suggested that eight embryonic development stages of Barbonymus gonionotus, namely early cleavage stage, morula stage, blastula stage, gastrula stage, bud stage, somite formation stage, hatching stage and larval stage (Myint and Soe, 2020), while in Puntius sealei absence of bud stage and combination of hatching and larval stage reduced the number of stages. Iswahyudi et al. (2014) proposed four stages namely morula, blastula, gastrula and organogenesis in Puntius binotatus from Indonesia. In a hybrid barb species 16 embronic development stages were observed by Zakaria et al. (2018) from Malaysia.

\section{Conclusions}

The eggs produced by the female Puntius sealei are small, spherical, semi-floating and adhesive but translucent. This study provided the first record of normal development of the Puntius sealei embryo, from fertilization to the post-hatching. In comparison to the rosy barb Puntius conchonius which belongs to the same genus, the embryonic development of Puntius sealei was found to differ slightly. Larvae produced seemed to bear no side effects from the induced spawning and appeared to be healthy. It was found that the use of Ovaprim to stimulate induced breeding in Puntius sealei is a highly feasible method with no apparent side effects on the embryonic development of the larvae. This study also demonstrated the reproducing of Puntius sealei larvae on a commercial scale for the ornamental or aquaculture purposes can be the possible alternative to non-native fish 
species. Further research is recommended especially in regards to the nutritional requirements of this species to further enhance the pool of knowledge regarding the potential of this species for aquaculture.

\section{Acknowledgements}

The authors would like to extend their gratitude to Dr. Juriah Kamaludeen and Dr. Hadi Hamli from Department of Animal Science and Fishery, Universiti Putra Malaysia Bintulu Sarawak Campus for their support during the study.

\section{Conflict of interest}

None to declare.

\section{Authors' contribution}

Conceptualization: Lirong Yu Abit, and Kamil Latif; methodology: Lirong Yu Abit, Edmond Felix Unggang, Abdulla-Al-Asif and Kamil Latif; data collection: Lirong Yu Abit and Edmond Felix Unggang; validation: Lirong Yu Abit and Abdulla-Al-Asif; data curation: Lirong Yu Abit and Abdulla-Al-Asif; writing - original draft preparation: Lirong Yu Abit, Edmond Felix Unggang, and Abdulla-Al-Asif; writing-review and editing: Lirong Yu Abit, Kamil Latif and Abdulla-Al-Asif; visualization: Lirong Yu Abit and Abdulla-Al-Asif; supervision: Kamil Latif; funding acquisition: Kamil Latif, all authors have read and agreed to the published version of the manuscript.

\section{References}

Basak SK, B Basak, N Gupta, SMM Rahman and DMM Haque, 2014. Embryonic and larval development of silver barb (Barbodes gonionotus) in a mobile hatchery under laboratory condition. IOSR J. Agri. Vet. Sci., 7: 81-90.

Bhattacharya H, SC Zhang and YJ Wang, 2005. Embryonic development of the rosy barb Puntius conchonius Hamilton 1822 (Cyprinidae). Trop. Zool., 18: 25-37.

Chong VC, PKY Lee and CM Lau, 2010. Diversity, extinction risk and conservation of Malaysian fishes. J. Fish Biol., 76: 2009-2066.

Doi A, T Iwata, M Inoue, H Miyasaka, MS Sabki and S Nakano, 2001. A collection of freshwater fishes from the Rayu Basin of Western Sarawak, Malaysia. Raffles Bull. Zool., 49: 13-17.

Epasinghe, EDM, AMAN Adikari, HMP Kithsiri, V Pahalawattarachchi, TADW Karunaratne and Inland, 2016. Induced breeding of Tinfoil Barb (Barbonymus schwanenfeldii) (Bleeker, 1854) using Ovaprime. Proc. Nat. Aqua. Res. Res. Dev. Agen. (NARA), 35-38.

Froese R and D Pauly, 2021. Puntius sealei (Herre, 1933). Fishbase. https://www.fishbase.in/summary/Puntiussealei.html

Grinang J, 2013. Fishes and Macroinvertebrates of Padawan Limestone, Sarawak, Malaysia. Borneo J. Res. Sci. Tech., 3: 1-14.

Hossain MT, MS Alam, MH Rahman, A Al-Asif and SM Rahmatullah, 2016. Present status of Indian major carp broodstock management at the hatcheries in Jessore region of Bangladesh. Asian-Austral. J. Biosci. Biotechnol., 1: 362-370.

Hui TH and DEM Husana, 2021. Barbodes pyrpholeos, new species, the first cave-dwelling cyprinid fish in the philippines, with redescription of B. Montanoi (teleostei: Cyprinidae). Raffles Bull. Zool., 69: 309-323.

Hui T and P Ng, 2005. The fighting fishes (Teleostei: Osphronemidae: Genus Betta) of Singapore, Malaysia and Brunei. Raffles Bull. Zool., 13: 43-99.

Islam MM, A Al-Asif and MR Amin, 2016. The induced breeding of common carps (Cyprinus carpio) in Bangladesh. Indian J. Sci., 23: 619-632.

Islam MS, A Al-Asif, B Sarker, A Satter, M Ahmed, M Rahman, MA Zafar and S Rahmatullah, 2017. Fry production and its marketing system of North-West fisheries extension project at Parbatipur, Dinajpur, Bangladesh. Asian J. Med. Biol. Res., 3: 368-378.

Ismail MA, MS Kamarudin, F Syukri, S Nur Ain and K Latif, 2019. Changes in the mouth morpho-histology of hybrid Malaysian mahseer (Barbonymus gonionotus $q \times$ Tor tambroides ${ }^{\lambda}$ ) during the larval development. Aquacul. Rep., 15: 100210.

Ismail MA, MS Kamarudin, F Syukri and K Latif, 2020. Larval development of a new hybrid Malaysian mahseer (Barbonymus gonionotus + + $\times$ Tor tambroides $\precsim$ ). Aquacul. Rep., 18: 100416.

Iswahyudi, Marsoedi and MS Widodo, 2014. Development of spotted barb (Puntius binotatus) eggs. J. Life Sci. Biomed., 4: 53-56. 
Jimmy EO, M Mohamed, S Harun and AH Fikri, 2010. The itchyofauna of Maliau Basin Conservation Area, Sabah, Malaysia, with special reference to the stream near Ginseng Camp. J. Trop. Biol.Conserv., 6: 55-59.

Kottelat M, AJ Whitten, Kartikasari and SN Wirjoatmodjo, 1993. Freshwater fishes of Western Indonesia and Sulawesi. Periplus Editions, Indonesia.

Kottelat M, 2012. Rasbora rheophila, a new species of fish from northern Borneo (Teleostei: Cyprinidae). Revue Suisse Zool., 119: 77-87.

Martin-Smith KM, 1996. Length/weight relationships of fishes in a diverse tropical freshwater community, Sabah, Malaysia. J. Fish Biol., 49: 731-734.

Mondal S, A Wahab, BK Barman and A Al-Asif, 2020. Breeding biology of mola carplet, (Amblypharyngodon mola, Hamilton, 1822) in semi-natural condition. Asian J. Anim. Sci., 14: 111-120.

Myint SS and AK Soe, 2020. Morphological embryonic development stages of Barbonymus gonionotus (Bleeker, 1850). IOP Conf. Ser. Earth Env. Sci., 416: 012003.

$\mathrm{Ng}$ CKC and J Tan, 2021. Cryptic species and grey zone speciation of the Barbodes binotatus complex (Teleostei, Cyprinidae) in Sundaland. J. Fish Biol., 99: 1256-1273.

Pethiyagoda R, M Meegaskumbura and K Maduwage, 2012. A synopsis of the South Asian fishes referred to Puntius (Pisces: Cyprinidae). Ichthyol. Expl. Freshwat., 23: 69-95.

Rachmatika I, R Nasi, D Sheil and M Wan, 2005. A first look at the fish species of the Middle Malinau: Taxonomy, ecology, vulnerability and importance. Center for International Forestry Research (CIFOR), Indonesia.

Rahman MA, MH Rahman, SM Yeasmin, A Al-Asif and D Mridha, 2017. Identification of causative agent for fungal infection and effect of disinfectants on hatching and survival rate of bata (Labeo bata) larvae. Adv. Plants Agri. Res., 7: 00264.

Rahman MH, MA Rahman, , MMM Hossain, SM Yeasmin, and A Al-Asif, 2016. Effect of feeding management of broodstock on breeding performance of bata (Labeo bata). Asian J. Med. Biol. Res., 1: 553568.

Rodolfo BR, 2021. Puntius sealei" in FishBase. FishBase. https://www.fishbase.se/summary/59488

Sadi A and H Biun, 2012. The ichtyofauna of Maliau Basin buzzer zone at Maliau Basin Conservation Area, Sabah, Malaysia. J. Trop. Biol. Conserv., 9: 105-113.

Sulaiman Z, TH Hui and KKP Lim, 2018. Annotated checklist of freshwater fishes from Brunei Darussalam, Borneo. Zootaxa, 4379: 24-46.

Sule HA, A Ismail and MNA Amal, 2016. A review of the ichthyofauna of Malaysian peat swamp forest. Pertanika J. Trop. Agri. Sci., 39: 421-458.

Wilkinson CL and TH Hui, 2018. Fishes of the brantian drainage, Sabah, Malaysia, with description of a new rasbora species (Teleostei: Cyprinidae). Raffles Bull. Zool., 66: 595-609.

Yeasmin SM, MA Rahman, MMM Hossain, MH Rahman and A Al-Asif, 2016. Identification of causative agent for fungal infection and effect of disinfectants on hatching and survival rate of common carp (C. carpio) larvae. Asian J. Med. Biol. Res., 1: 578-588.

Yeasmin SM, MH Rahman, MA Rahman, A Al-Asif, MA Farid and MM Billah, 2018. Influence of feeding administration of brood-stock on breeding performance of common carp (Cyprinus carpio Linnaeus, 1758). J. Aqua. Eng. Fish. Res., 4: 127-137.

Yu Abit L, IS Kamaruddin, Z Mohd-Rozhan, MY Ina-Salwany and AS Mustafa-Kamal, 2012. Fish biodiversity survey (2009) of streams in the Ayer Hitam forest reserve, Puchong, Selangor. Pertanika J. Trop. Agri. Sci., 35: 15-19.

Zakaria MH, SMN Amin, N Romano, A Arshad, MA Rahman and SG Lee, 2018. Embryonic and larval development of lemon fin barb hybrid (ổ Hypsibarbus wetmorei $\times$ Barbonymus gonionotus). J. Env. Biol., 39: 732-740. 